conformation [21]. di Viti et al suggests that the SARS-CoV-2 may be less virulent than the SARS-CoV and MERS-CoV, with the currently analyzed mortality of COVID-19 is $3.4 \%$, lower than death rate of SARS (9.6\%) and MERS (around 35\%), respectively [22]

\section{Role of ACE2 gene}

SARS-CoV-2 uses angiotensin-converting enzyme 2 (ACE2), which serves as a receptor for SARS-CoV for viral entry into the host cell $[23,24]$. The ACE2 gene is located in X chromosome; potential functional variants of ACE2 gene are shown to alter its transcriptional activity [25].

Varying allele frequencies are exhibited by some single nucleotide polymorphisms (SNPs) located in the coding regions of ACE2 gene [26]. Compared to a global average of American and European population, SNPs like rs758278442 and rs759134032 in the region of protective variants (K31R and Y83H) of ACE2 gene show relatively higher frequency of mutant alleles in Asian population. However, compared to African and Asian population, people of European descent have a higher frequency of alternate allele of rs763395248 SNP in T92I risk variant. Certain ACE2 variants might provide potential resistance to SARS-CoV-2 infection according to a structural modelling study [27]. Additionally, the expression quantitative trait loci (eQTL) analysis of ACE2 variants revealed association of some eQTLs with higher expression of ACE2 in tissues and few eQTLs had higher allele frequencies in East Asian Populations than the European populations [26]

Significant allele frequency differences of the missense mutations (K26R, 1468V, N720D, and N638S) of ACE2 gene were detected in various populations. Within these, $1468 \mathrm{~V}$ mutated more frequently in Asians, whereas K26R mutated more frequently among Caucasians. Variable ACE2 gene expression was reported among different populations, but the magnitude was found to be very minute [28]. However, Chen et al noted that people of Asian descent exhibit similar ACE2 expression like other groups and that no significant differences in gene expressions were reported [29].

\section{Clinical implications of ACE2 Gene}

The most common comorbid conditions in COVID-19, Hypertension and Diabetes mellitus (DM) are both are modulated by ACE2 [30]. ACE2 plays a major role in inflammatory processes [31]. Genetic deficiency of ACE2 upregulates the expression of cytokines and induces vascular inflammation in ApoE knockout mouse model [32].Multiple immune signatures such as markers of T cells, B cells, NK cells, and interferon response across various human tissues were found to be associated with ACE2 expression [33]. Therefore, these findings can imply that ACE2 is also involved in mediating the postinfection downstream processes including inflammatory responses, rather than just acting as a receptor for SARS-CoV-2 [25].

\section{CONCLUSION}

Genome structure of SARS-CoV-2 is very similar to that of SARS$\mathrm{CoV}$ and MERS-CoV viruses. $\mathrm{L}$ and $\mathrm{S}$ strains were isolated in Wuhan. Later A, B and C types were isolated, A and $\mathrm{C}$ being most common in the Americas and Europe and B being most common in Asia. This data may have helped in the production of country specific or ethnicity specific vaccines.

SNPs like rs758278442 and rs759134032 in the region of protective variants (K31R and $\mathrm{Y} 83 \mathrm{H})$ of ACE2 gene show relatively higher frequency of mutant alleles in Asian population than American and European populations, while people of European descent have a higher frequency of alternate allele of rs 763395248 SNP in T92I risk variant compared to African and Asian population. According to a structural modelling study, certain ACE2 variants may provide potential resistance to SARS-CoV-2 infection.

\section{REFERENCES}

1. Lu, G.; Wang, Q.; Gao, G.F. Bat-to-human: Spike features determining 'host jump' of coronavir

Wu F, Zhao S, Yu B, Chen YM, Wang W, Song ZG, et al. A new coronavirus associated with human respiratory disease in China. Nature. 2020. https:// doi.org/10.1038/s41586020-2008-3 [Epub ahead of print].

3. de Wit E, van Doremalen N, Falzarano D, Munster VJ. SARS and MERS: recent insights into emerging coronaviruses. Nat Rev Microbiol. 2016;14(8): 523-34.

4. Song Z, Xu Y, Bao L, Zhang L, Yu P, Qu Y, et al. From SARS to MERS, thrusting coronaviruses into the spotlight. Viruses, 2019;11(1):E59, https:// doi.org/10.3390/v11010059.

5. Kim, D.; Lee, J.Y.; Yang, J.S.; Kim, J.W.; Kim, V.N.; Chang, H. The Architecture of
SARS-CoV-2 Transcriptome. Cell 2020, 181, 1-8.

Gordon, D.E.; Jang, G.M.; Bouhaddou, M.; Xu, J.; Obernier, K.; White, K.M.; O'Meara, M.J.; Rezelj, V.V.; Guo, J.Z.; Swaney, D.L.; et al. A SARS-CoV-2-Human ProteinProtein Interaction Map Reveals Drug Targets and Potential Drug-Repurposing. Nature 2020, in press.

7. Li, W.; Shi, Z.; Yu, M.; Ren, W.; Smith, C.; Epstein, J.H.; Wang, H.; Crameri, G.; Hu, Z.; Zhang, H.; et al. Bats are natural reservoirs of SARS-like coronaviruses. Science 2005 , $310,676-679$

8. Ceraolo, C.; Giorgi, F.M. Genomic variance of the 2019-nCoV coronavirus. J. Med. Virol. 2020, 92, 522-528

9. Tang, T.; Wu, C.; Li, X.; Song, Y.; Yao, X.; Wu, X.; Duan, Y.; Zhang, H.; Wang, Y.; Qian, Z.; et al. On the origin and continuing evolution of SARS-CoV-2. Natl. Sci. Rev. 2020, in press.

10. Liu, P. Chen, W.; Chen, J.P. Viral Metagenomics Revealed Sendai Virus and Coronavirus Infection of Malayan Pangolins (Manis javanica). Viruses 2019, 11, 979

11. Forster, P.; Forster, L.; Renfrew, C.; Forster, M. Phylogenetic network analysis of SARSCoV-2 genomes. Proc. Natl. Acad. Sci. USA 2020, 117, 9241-9243.

12. Zhang N, Jiang S, Du L. Current advancements and potential strategies in the development of MERS-CoV vaccines. Expert Rev Vaccines. 2014;13(6):761-74

13. Xia S, Zhu Y, Liu M, Lan Q, Xu W, Wu Y, et al. Fusion mechanism of 2019- nCoV and fusion inhibitors targeting HR1 domain in spike protein. Cell Mol Immunol. 2020 https://doi.org/10.1038/s41423-020-0374-2

14. Yu F, Du L, Ojcius DM, Pan C, Jiang S. Measures for diagnosing and treating infection by a novel coronavirus responsible for a pneumonia outbreak originating in Wuhan, China. Microbes Infect. 2020. https://doi.org/10.1016/j. micinf.2020.01.003 [Epub ahead of print].

15. de Wilde AH, Snijder EJ, Kikkert M, van Hemert MJ. Host factors in coronavirus replication. Curr Top Microbiol Immunol. 2018;419:1-42

16. Sawicki SG, Sawicki DL. Coronavirus transcription: a perspective. Curr Top Microbio Immunol. 2005;287:31-55.

17. Hussain S, Pan J, Chen Y, Yang Y, Xu J, Peng Y, et al. Identification of novel subgenomic RNAs and noncanonical transcription initiation signals of severe acute respiratory syndrome coronavirus. J Virol. 2005;79(9):5288-95.

18. Perrier A, Bonnin A, Desmarets L, Danneels A, Goffard A, Rouille Y, et al. The Cterminal domain of the MERS coronavirus $\mathrm{M}$ protein contains a transGolgi network localization signal. J Biol Chem. 2019;294(39):14406-21.

19. Guo, YR., Cao, QD., Hong, ZS. et al. The origin, transmission and clinical therapies on coronavirus disease 2019 (COVID-19) outbreak - an update on the status. Military Med Res 7, $11(2020)$

20. Letko M, Marzi A, Munster V. Functional assessment of cell entry and receptor usage for SARS-CoV-2 and other lineage B betacoronaviruses. Nat Microbiol. 2020 https://doi.org/10.1038/s41564-020-0688-y.

21. Song W, Gui M, Wang X, Xiang Y. Cryo-EM structure of the SARS coronavirus spike glycoprotein in complex with its host cell receptor ACE2. PLoS Pathog. 2018;14(8):e1007236.

22. de Wit E, van Doremalen N, Falzarano D, Munster VJ. SARS and MERS: recent insight into emerging coronaviruses. Nat Rev Microbiol. 2016;14(8): 523-34

23. Li W, Moore MJ, Vasilieva N, et al. Angiotensin-converting enzyme 2 is a functional receptor for the SARS coronavirus. Nature. 2003;426(6965):450-454

24. Hoffmann M, Kleine-Weber H, Schroeder S, et al. SARS-CoV-2 cell entry depends on ACE2 and TMPRSS2 and is blocked by a clinically proven protease inhibitor. Cell. 2020;181(2):271-280. e8.

25. Debnath, M, Banerjee, M, Berk, M. Genetic gateways to COVID- 19 infection: Implications for risk, severity, and outcomes. The FASEB Journal. 2020; 34:87878795. https://doi.org/10.1096/fj.202001115R

26. Cao Y, Li L, Feng Z, et al. Comparative genetic analysis of the novel coronavirus (2019nCoV/SARS-CoV-2) receptor ACE2 in different populations. Cell discovery. 2020;6:11

27. Hussain EW, Diwanji D, Suryamohan K, et al. Structural variations in human ACE2 may influence its binding with SARS-CoV-2 spike protein. J Med Virol. 2020 doi: $10.1002 / \mathrm{jmv} .25832$

28. Li Q, Cao Z, Rahman P. Genetic variability of human angiotensin-converting enzyme 2 (hACE2) among various ethnic populations. BioRxiv. 2020. https://doi.org $10.1101 / 2020.04 .14 .041434$

29. Chen Y, Shan K, Qian W. Asians and other races express similar levels of and share the same genetic polymorphisms of the SARSCoV-2 cell-entry receptor. Preprints. 2020:2020020258. https:// doi.org/10.20944/preprints202002.0258.v1

30. Patel VB, Bodiga S, Basu R, et al. Loss of angiotensin-converting enzyme-2 exacerbates diabetic cardiovascular complications and leads to systolic and vascular dysfunction: critical role of the angiotensin II/AT1 receptor axis. Circ Res. 2012;110:1322-1335.

31. Gaddam RR, Chambers S, Bhatia M. ACE and ACE2 in inflammation: a tale of two enzymes. Inflamm Allergy Drug Targets. 2014;13:224-234.

32. Thomas MC, Pickering RJ, Tsorotes D, et al. Genetic Ace2 deficiency accentuate vascular inflammation and atherosclerosis in the ApoE knockout mouse. Circ Res. 2010;107:888-897

33. Li M-Y, Li L, Zhang Y, Wang X-S. Expression of the SARS-CoV-2 cell receptor gene ACE2 in a wide variety of human tissues. Infect Dis Poverty. 2020;9:4 